\title{
Chemistry and structure by design: ordered CuNi(CN)4 sheets with copper(II) in a square-planar environment
}

Article

Accepted Version

Chippindale, A. M., Hibble, S. J., Marelli, E., Bilbe, E. J., Hannon, A. C. and Zbiri, M. (2015) Chemistry and structure by design: ordered $\mathrm{CuNi}(\mathrm{CN}) 4$ sheets with copper(II) in a squareplanar environment. Dalton Transactions, 44 (28). pp. 1250212506. ISSN 1364-5447 doi:

https://doi.org/10.1039/c5dt01127b Available at https://centaur.reading.ac.uk/40776/

It is advisable to refer to the publisher's version if you intend to cite from the work. See Guidance on citing.

To link to this article DOI: http://dx.doi.org/10.1039/c5dt01127b

Publisher: Royal Society of Chemistry

All outputs in CentAUR are protected by Intellectual Property Rights law, including copyright law. Copyright and IPR is retained by the creators or other copyright holders. Terms and conditions for use of this material are defined in the End User Agreement. 


\section{CentAUR}

Central Archive at the University of Reading

Reading's research outputs online 


\section{COMMUNICATION}

Chemistry and Structure by Design: Ordered

Cite this: DOI: 10.1039/xoxxooooox $\mathrm{CuNi}(\mathrm{CN})_{4}$ Sheets with Copper(II) in a Square-Planar Environment

Received ooth January 2012, Accepted ooth January 2012

DOI: 10.1039/xoxxooooox

A. M. Chippindale, ${ }^{* a}$ S. J. Hibble, ${ }^{* b}$ E. Marelli, ${ }^{a}$ E. J. Bilbe, ${ }^{a}$ A. C. Hannon ${ }^{c}$ and M. Zbiri $^{d}$

www.rsc.org/ 


\section{COMMUNICATION}

Layered copper-nickel cyanide, $\mathrm{CuNi}(\mathrm{CN})_{4}$, a 2-D negative thermal expansion material, is one of a series of copper(II)containing cyanides derived from $\mathrm{Ni}(\mathrm{CN})_{2}$. In $\mathrm{CuNi}(\mathrm{CN})_{4}$, unlike in $\mathrm{Ni}(\mathrm{CN})_{2}$, the cyanide groups are ordered generating square-planar $\mathrm{Ni}(\mathrm{CN})_{4}$ and $\mathrm{Cu}(\mathrm{NC})_{4}$ units. The adoption of square-planar geometry by $\mathrm{Cu}(\mathrm{II})$ in an extended solid is very unusual.

The simple binary copper(II) cyanide, $\mathrm{Cu}(\mathrm{CN})_{2}$, does not exist. The reaction of $\mathrm{Cu}$ (II) in aqueous solution with the pseudohalide cyanide ion reacts via a number of steps to produce cyanogen and copper(I) cyanide, $\mathrm{CuCN} .{ }^{1}$ This is reminiscent of the reaction familiar to chemistry undergraduates in which the iodide ion reacts with copper(II) to produce iodine and copper(I) iodide. ${ }^{2}$

$2 \mathrm{Cu}^{2+}+4 \mathrm{X}^{-}=2 \mathrm{CuX}+\mathrm{X}_{2} \quad\left(\mathrm{X}=\mathrm{I}^{-}, \mathrm{CN}^{-}\right)$

Our challenge was to stabilize $\mathrm{Cu}(\mathrm{II})$ with respect to the internal redox reaction in the presence of cyanide ligands only. This has been achieved by replacement of half of the $\mathrm{Ni}$ (II) in anhydrous nickel cyanide, $\mathrm{Ni}(\mathrm{CN})_{2}$, by $\mathrm{Cu}(\mathrm{II})$ to form $\mathrm{CuNi}(\mathrm{CN})_{4}$. In $\mathrm{Ni}(\mathrm{CN})_{2}$, each $\mathrm{Ni}$ atom is linked by four linear, bridging cyanide ions to four other nickel atoms to form planar $\mathrm{Ni}(\mathrm{CN})_{2}$ sheets with head-to-tail cyanide disorder. ${ }^{3-5}$ By using the square-planar ion, $\left[\mathrm{Ni}(\mathrm{CN})_{4}\right]^{2-}$, as a synthon and linking such units by $\mathrm{Cu}^{2+}$ ions, a modified $\mathrm{Ni}(\mathrm{CN})_{2}$ sheet structure can be assembled in which the copper atoms have squareplanar geometry and are coordinated only to cyanide ligands via nitrogen to generate an ordered sheet (Figure 1). \#

Although there are a number of examples of molecular species containing square-planar $\mathrm{Cu}(\mathrm{II})$ with, for example, phthalocyanines and $\mathrm{N}$ and $\mathrm{O}$ donor ligands, ${ }^{7,8}$ we believe that the layered product, $\mathrm{CuNi}(\mathrm{CN})_{4}$, is the first example of a simple extended solid containing $\mathrm{Cu}^{2+}\left(d^{9}\right)$ ions in X-ray diffraction patterns of $\mathrm{CuNi}(\mathrm{CN})_{4}$ at 30,180 and $270{ }^{\circ} \mathrm{C}(303,453$ and $543 \mathrm{~K})$ square-planar coordination. The separation between adjacent $\mathrm{CuNi}(\mathrm{CN})_{4}$ layers at $3.09 \AA$ is too great for significant interlayer interactions to occur, precluding Jahn-Teller distortion of octahedral geometry to produce $(4+2)$ coordination, as is frequently observed in $\mathrm{Cu}^{2+}$ compounds. Further exploration of the $\mathrm{Cu}(\mathrm{II})-\mathrm{Ni}(\mathrm{II})$ cyanide phase diagram shows that $\mathrm{Cu}(\mathrm{II})$ containing compounds also exist both as hydrates, $\mathrm{Cu}_{x} \mathrm{Ni}_{1-x}(\mathrm{CN})_{2} \cdot 3 \mathrm{H}_{2} \mathrm{O}$, and dehydrated phases, $\mathrm{Cu}_{x} \mathrm{Ni}_{1-x}(\mathrm{CN})_{2}$, forming solid solutions over the range $(0 \leq x \leq 0.25)$.

The addition of $\mathrm{Cu}^{2+}$ ions to $\mathrm{Ni}(\mathrm{CN})_{4}{ }^{2-}$ in aqueous solution immediately produces a blue-green gelatinous precipitate (vide infra), which on stirring for several hours transforms to a grey solid, characterised as $\mathrm{CuNi}(\mathrm{CN})_{4}$. On heating $\mathrm{CuNi}(\mathrm{CN})_{4}$ under nitrogen at $680 \mathrm{~K}$, copper(II) is reduced by cyanide to produce copper(I) cyanide and paracyanogen, together with nickel cyanide, according to the reaction:

$\mathrm{Cu}^{\mathrm{II}} \mathrm{Ni}(\mathrm{CN})_{4}=\mathrm{Ni}(\mathrm{CN})_{2}+\mathrm{Cu} \mathrm{I}^{\mathrm{I} N}+(\mathrm{CN})_{n}$

Figure 2 shows the powder $\mathrm{X}$-ray diffraction patterns obtained for $\mathrm{CuNi}(\mathrm{CN})_{4}$ and $\mathrm{Ni}(\mathrm{CN})_{2}$. The Bragg peak positions and relative intensities show the close underlying similarity of the two structures and confirm that $\mathrm{CuNi}(\mathrm{CN})_{4}$ is a layered material. The difference in peak widths in the two diffraction patterns arises mainly from the difference in crystallite size of the two materials. The Raman spectrum of $\mathrm{CuNi}(\mathrm{CN})_{4}$ exhibits $2 v_{\mathrm{C} \equiv \mathrm{N}}$ stretches, at 2209 and 2184 $\mathrm{cm}^{-1}$, and the infrared spectrum has one non-coincident $v_{\mathrm{C}=\mathrm{N}}$ stretch at $2182 \mathrm{~cm}^{-1}$. These observations are consistent with $D_{4 h}$ symmetry of the individual metal-cyanide layers. Only two arrangements of the

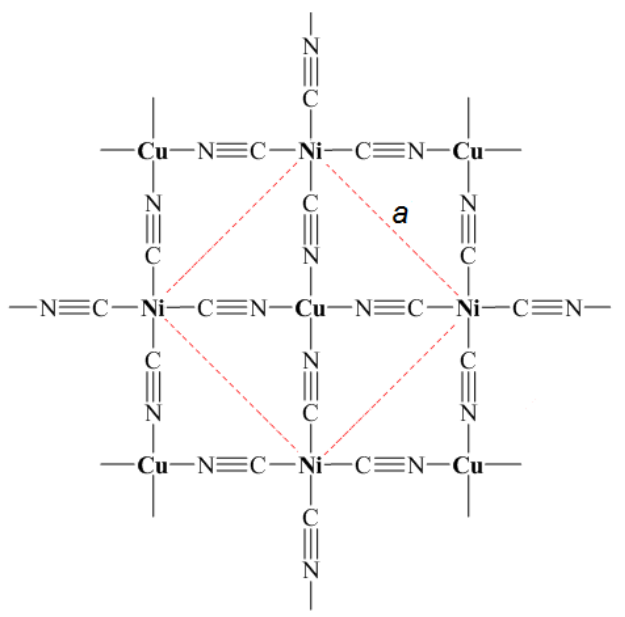

Fig. 1 Representation of a layer of $\mathrm{CuNi}(\mathrm{CN})_{4}$ with square-planar geometry around both $\mathrm{Cu}^{2+}$ and $\mathrm{Ni}^{2+}$ ions. The structural repeat unit within the layer is shown in the red square of length $a$.

metal atoms and cyanide groups within each layer are therefore possible: namely, the one shown in Figure 1, with the carbon end of the cyanide ligand attached to nickel and the nitrogen end to copper, or the inverted arrangement with the carbon end attached to copper. Of these two possibilities, only the first arrangement yields a good fit to the low $r$ region $(0<r / \AA<3)$ of the total correlation function, $T^{\mathrm{N}}(r)_{\exp }$, obtained from neutron diffraction (Figure 3 and S.10) confirming that the metals and cyanide groups in $\mathrm{CuNi}(\mathrm{CN})_{4}$ are indeed arranged as shown in Figure 1. The bond lengths obtained from the fitting of individual peaks in $T^{\mathrm{N}}(r)_{\exp }$ at $15 \mathrm{~K}$ are: $\mathrm{C} \equiv \mathrm{N}$, 1.1541(6); Ni-C, 1.857(1) and $\mathrm{Cu}-\mathrm{N}, 1.943(2) \AA$.

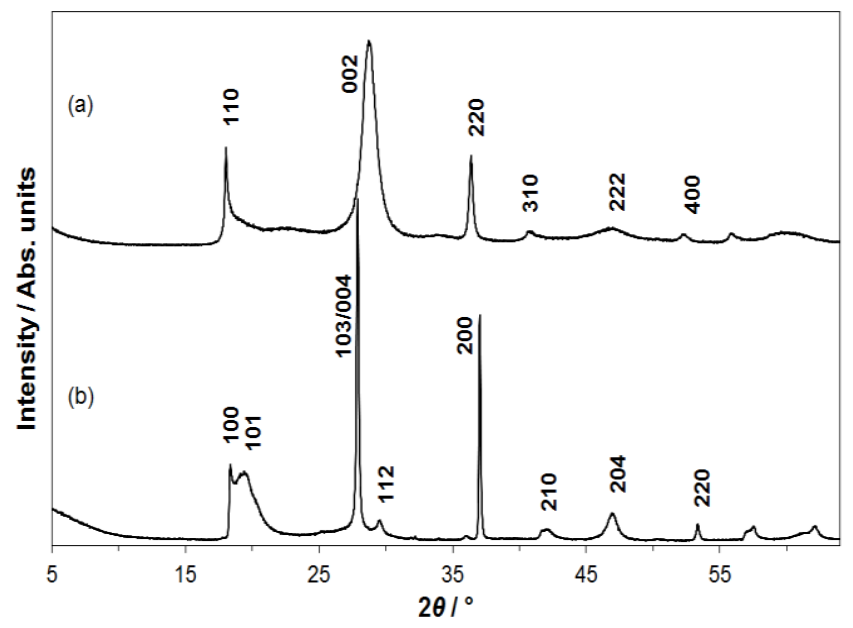

Fig. 2 Powder X-ray diffraction patterns at $295 \mathrm{~K}$ of (a) $\mathrm{CuNi}(\mathrm{CN})_{4}$ $(a=6.957(1)$ and $c=6.180(6) \AA)$ and (b) $\mathrm{Ni}(\mathrm{CN})_{2}(a=4.857$ and $c$ $=12.802 \AA)^{3}\left(\mathrm{Cu} K \alpha_{1}\right.$ radiation, $\left.\lambda=1.54060 \AA\right)$ showing Miller indices of the principal reflections.

Taking into account the metal and cyanide ordering within the layers determined above, the powder X-ray diffraction pattern for 
$\mathrm{CuNi}(\mathrm{CN})_{4}$ can be indexed on a tetragonal unit cell $(a=6.957(1)$ and $c=6.180(6) \AA$ ) (Figure 2). This unit cell is related to that of $\mathrm{Ni}(\mathrm{CN})_{2}$. The $a$ lattice parameter in $\mathrm{CuNi}(\mathrm{CN})_{4}$ is $\sim \sqrt{2}$ of the value for $\mathrm{Ni}(\mathrm{CN})_{2}$ as a consequence of the ordering of the $\mathrm{Cu}$ and $\mathrm{Ni}$ atoms within the layers. X-ray and neutron diffraction experiments ${ }^{3}$ show no evidence of cyanide ordering within the nickel-cyanide layers in $\mathrm{Ni}(\mathrm{CN})_{2}$ and in this case, the $a$ lattice parameter corresponds to the direct $\mathrm{M}-\mathrm{CN}-\mathrm{M}$ distance shown in Figure 1. The $c$ lattice parameter chosen for $\mathrm{CuNi}(\mathrm{CN})_{4}$ corresponds to a two-layer repeat, $A B A B$, and a physically reasonable interlayer separation of $\sim 3.09 \AA$. Although a $c$ lattice parameter of $1 / 2$ this value could be used to index fully the powder X-ray pattern of $\mathrm{CuNi}(\mathrm{CN})_{4}$, this would be physically unreasonable as in the resulting $A A A$ stacking, the atoms in adjacent layers would lie directly above each other and hence be impossibly close together. The stacking sequence in $\mathrm{Ni}(\mathrm{CN})_{2}$ is more complicated with a four-layer repeat predominating ${ }^{3,4}$ resulting in a $c$ lattice parameter of $\sim 12.8 \AA$ and the appearance of the broad reflection, indexed as (101), seen at $2 \theta \sim 20^{\circ}$ (Figure 2(b)).

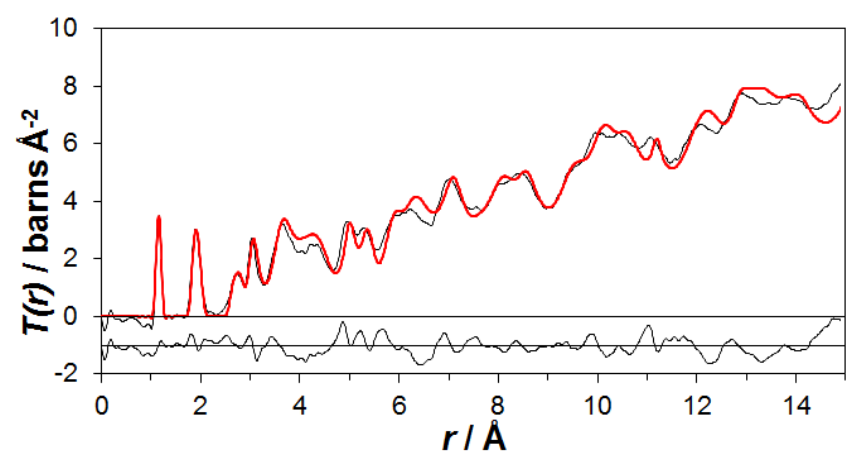

Fig. 3 Total correlation functions for $\mathrm{CuNi}(\mathrm{CN})_{4}$ at $15 \mathrm{~K}: T^{\mathrm{N}}(r)_{\exp }$, (black line) and, for a model in $C m c m, T^{\mathrm{N}}(r)_{\bmod }$ (red line). The difference function is shown at the bottom of the plot (offset for clarity by 1 barns $\AA^{-2}$ ).

Using the $\mathrm{Cu}-\mathrm{N}, \mathrm{Ni}-\mathrm{C}$ and $\mathrm{C} \equiv \mathrm{N}$ bond lengths obtained from fitting the low $r$ region of $T^{\mathrm{N}}(r) \exp$ (Figure 3), together with the unit-cell parameters obtained from the powder X-ray diffraction pattern and including the $A B A B$ stacking of the layers, a 3-D model was constructed in space group $\mathrm{Cmcm}$ (Figure 4). This model reproduces $T^{\mathrm{N}}(r)_{\exp }$ to $r=15 \AA$ well (Figure 3 ) and is thus a good representation of the short- and medium-range structure in the material. $\$$ It should be noted that this conventional crystallographic model does not fully reproduce the powder X-ray diffraction pattern in Figure 2 because in $\mathrm{CuNi}(\mathrm{CN})_{4}$, there is extensive stacking disorder, as evidenced by the shape of the (110) reflection (Figure 2). Hence although the model gives a good description of the short- and medium-range order in $\mathrm{CuNi}(\mathrm{CN})_{4}$, the chemically important information, it needs to be combined with a model of the stacking disorder in order to reproduce the powder X-ray pattern. Indeed, an appropriate calculation demonstrating this has already been carried out in a previous paper ${ }^{4}$ in which different types of stacking disorder were considered for $\mathrm{Ni}(\mathrm{CN})_{2}$ and has validity in the present case as the $\mathrm{X}$ ray scattering factors of $\mathrm{Cu}$ and $\mathrm{Ni}$ are very similar (as indeed are those of $\mathrm{C}$ and $\mathrm{N}$ ). The simulated powder $\mathrm{X}$-ray diffraction pattern in which the sequence $A B$ is followed by A occurs with a probability of $75 \%$ gives a good match to our observed pattern. In contrast, in $\mathrm{Ni}(\mathrm{CN})_{2}$, the most probable stacking sequence $(67 \%)$ is that the sequence $A B$ is followed by a third layer, $A^{\prime}$, which is offset with respect to both $A$ and $B$.

Layered inorganic materials are currently attracting much interest, particularly with respect to their electronic, optical and mechanical properties. ${ }^{9}$ Although graphene and metal disulfides are the most widely studied, a recent paper utilising DFT calculations has suggested that $\mathrm{Ni}(\mathrm{CN})_{2}$ should have interesting electronic properties when in the form of individual sheets and, by analogy with graphene, when rolled into nanotubes, particularly if it can be $n$ or $p$ doped. ${ }^{10}$ Mo and Kaxiras proposed that doping could be achieved by replacing some of the $-\mathrm{C} \equiv \mathrm{N}-$ linkages by $-\mathrm{C} \equiv \mathrm{C}-$ or $-\mathrm{N}=\mathrm{N}-$ groups to produce either $p$ - or $n$ - doped structures. In our synthesis of $\mathrm{CuNi}(\mathrm{CN})_{4}$, we have effectively substituted on the metal sites in $\mathrm{Ni}(\mathrm{CN})_{2}$, rather than the non-metal sites.. By replacing half the $\mathrm{Ni}^{2+}$ by $\mathrm{Cu}^{2+}$ in $\mathrm{Ni}(\mathrm{CN})_{2}$ to form $\mathrm{CuNi}(\mathrm{CN})_{4}$, we have achieved an extremely high level of $n$ doping of the layers. The magnetic susceptibility of $\mathrm{CuNi}(\mathrm{CN})_{4}$ has the value $\mu=1.76 \mu$ в at $295 \mathrm{~K}$, which is consistent with isolated moments on $\mathrm{Cu}^{2+}$ ions $\left(d^{9}\right)$, and unfortunately indicates that a delocalised electron system is not formed. The presence of an absorption band centred at $\sim 17000 \mathrm{~cm}^{-1}$ in the diffuse reflectance spectrum of $\mathrm{CuNi}(\mathrm{CN})_{4}$ can be ascribed to a $d$ - $d$ transition(s) and is unobserved in the corresponding spectrum of $\mathrm{Ni}(\mathrm{CN})_{2}$ (Figure 5). From the reflectance spectra, the optical band gaps for $\mathrm{Ni}(\mathrm{CN})_{2}$ and $\mathrm{CuNi}(\mathrm{CN})_{4}$ are determined to be 16100 and $21780 \mathrm{~cm}^{-1}(2$ and $2.7 \mathrm{eV})$, respectively, showing that this degree of substitution of $\mathrm{Ni}$ by $\mathrm{Cu}$ has produced a poorer semiconductor as a result of ordering within the metal-cyanide sheets.

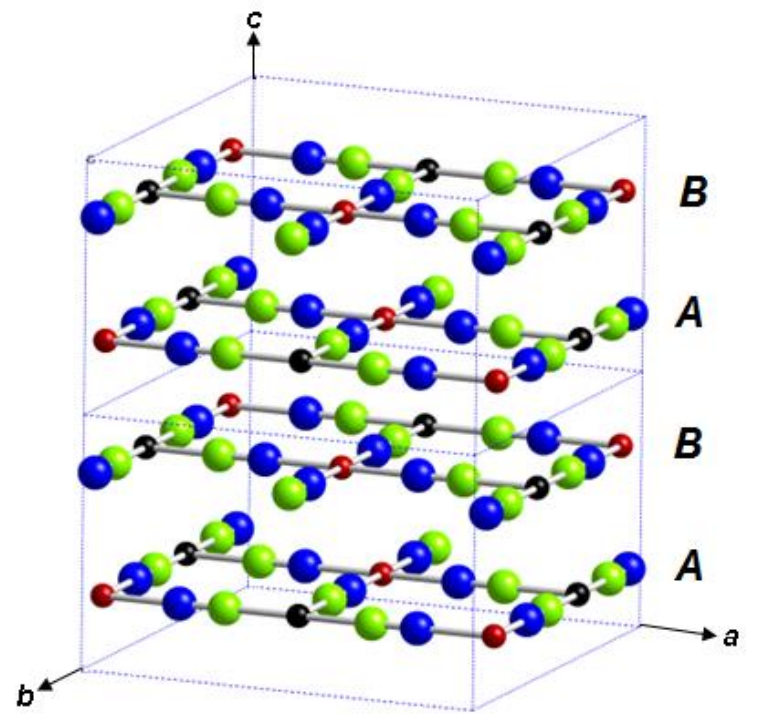

Fig. 4 Model of $\mathrm{CuNi}(\mathrm{CN})_{4}$ in space group $\mathrm{Cmcm}(a=b=9.9082$ and $c=6.100 \AA$ ) showing the $A B A B$ stacking of the ordered layers. (Key: copper atoms, orange spheres; nickel atoms, black spheres; carbon atoms, green spheres and nitrogen atoms, blue spheres).

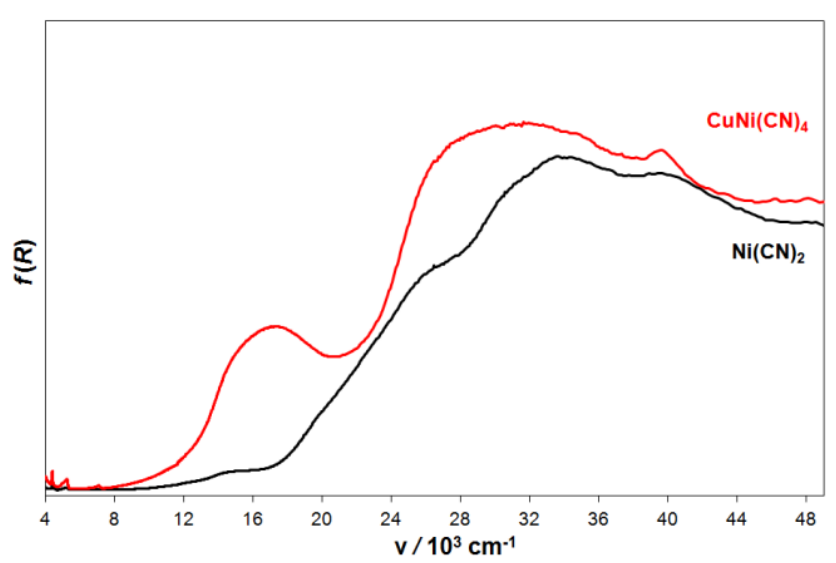

Fig. 5 Diffuse reflectance spectra of $\mathrm{CuNi}(\mathrm{CN})_{4}$ (red) and $\mathrm{Ni}(\mathrm{CN})_{2}$ (black) 
Considering mechanical properties, $\mathrm{CuNi}(\mathrm{CN})_{4}$ shows twodimensional negative thermal expansion with $\alpha_{a}=-9.7(8) \times 10^{-6} \mathrm{~K}^{-1}$ (where $\alpha_{a}=\left(a_{T 2}-a_{T 1}\right) / a_{T 1}\left(T_{2}-T_{1}\right)$ (Figure 6)) which is of a similar magnitude to that measured for graphene ${ }^{11}$ and $\sim 1.5$ times the value for $\mathrm{Ni}(\mathrm{CN})_{2}$. Inelastic neutron scattering and DFT studies on $\mathrm{Ni}(\mathrm{CN})_{2}$ at ambient ${ }^{5}$ and high pressure ${ }^{12}$ show that it is the atomic motions perpendicular to the metal-cyanide sheets that give rise to the 2-D NTE behaviour and it is anticipated that similar mechanism will apply in the case of $\mathrm{CuNi}(\mathrm{CN})_{4}$. Figure 6 shows the relative percentage changes in the $a$ and $c$ lattice parameters and cell volume, $V$, for $\mathrm{CuNi}(\mathrm{CN})_{4}$ and $\mathrm{Ni}(\mathrm{CN})_{2}$. Although $\alpha_{a}$ is independent of temperature over the temperature range of this study for both $\mathrm{CuNi}(\mathrm{CN})_{4}$ and $\mathrm{Ni}(\mathrm{CN})_{2}$, the temperature dependence of $\alpha_{c}$ is different for the two materials. For $\mathrm{CuNi}(\mathrm{CN})_{4}, \alpha_{c}$ is non linear with temperature, whereas for $\mathrm{Ni}(\mathrm{CN})_{2}$, it is, like $\alpha_{a}$, independent of temperature. An explanation of the difference in the form of the variation of the $c$ parameter with temperature, and hence also cell volume, requires a detailed comparison of the phonon density of states of $\mathrm{CuNi}(\mathrm{CN})_{4}$ and $\mathrm{Ni}(\mathrm{CN})_{2}$ to be carried out over a comparable temperature range.

As well as being mechanically different from $\mathrm{Ni}(\mathrm{CN})_{2}$, copper nickel cyanide, $\mathrm{CuNi}(\mathrm{CN})_{4}$, is chemically different in that it does not form hydrates. Indeed, it can be obtained directly from aqueous solution as the anhydrous compound, as described above. (Similar reactions using only nickel reagents, e.g. $\mathrm{Ni}^{2+}+\mathrm{Ni}(\mathrm{CN})_{4} 4^{2-}$, produce layered nickel-cyanide hydrates, $\mathrm{Ni}(\mathrm{CN})_{2} . n \mathrm{H}_{2} \mathrm{O}(n=3,3 / 2)$, containing $\mathrm{Ni}(\mathrm{NC})_{4}\left(\mathrm{H}_{2} \mathrm{O}\right)_{2}$ and $\mathrm{Ni}(\mathrm{CN})_{4}$ units, and dehydration is required to form $\left.\mathrm{Ni}(\mathrm{CN})_{2}\right){ }^{3}$

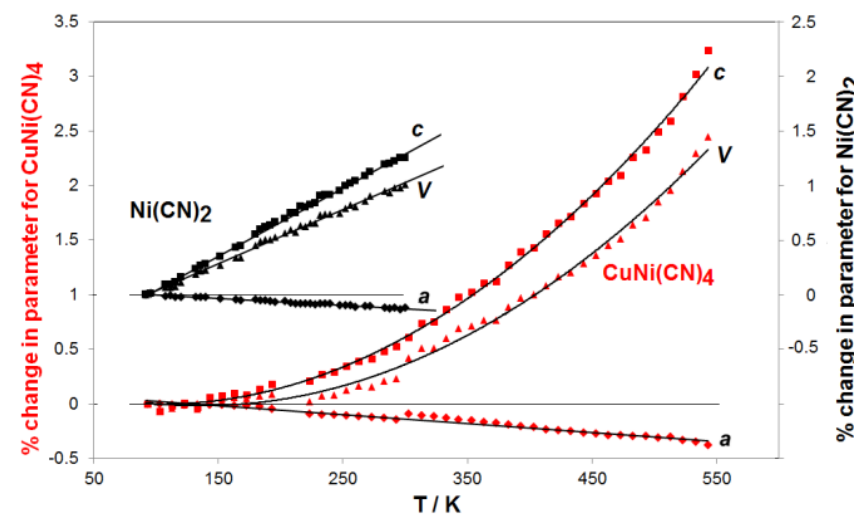

Fig. 6 The relative percentage changes in the $a$ and $c$ lattice parameters and volume, $V$, for $\mathrm{CuNi}(\mathrm{CN})_{4}$ and $\mathrm{Ni}(\mathrm{CN})_{2}{ }^{3}$ over the temperature ranges $(93-543) \mathrm{K}$ and $(95-295) \mathrm{K}$, respectively. The relative $\%$ change of a parameter, $l_{T 2}$, is given by $100 \times\left(l_{T 2}-l_{T 1}\right) / l_{T 1}$, where $l_{T 2}$ is the parameter $l$ at temperature $T_{2}$, and $l_{T 1}$ is the parameter $l$ at the lowest temperature, $T_{1}$.

$\mathrm{CuNi}(\mathrm{CN})_{4}$ is probably initially formed as individual layers. Mixing the salt solutions produces at first a blue gel, which turns grey on ageing in solution or on drying as the individual layers aggregate to form stacks. The powder X-ray diffraction patterns shown in Figure 7 provide evidence that the material grows only slowly in the [001] direction. Even in its final grey form, the stacks in $\mathrm{CuNi}(\mathrm{CN})_{4}$ are only $\sim 40 \AA$ thick (as estimated by using the Scherrer equation applied to the (002) reflection). The slow growth in the $c$ direction occurs possibly because the bonding between the layers is weak. Support for this hypothesis comes from the ease of separating the layers to make intercalation compounds. For example, stirring $\mathrm{CuNi}(\mathrm{CN})_{4}$ in 4,4 '-bipyridine in ethanol at room temperature produces a blue-grey solid with an interlayer separation of $\sim 11.3 \AA$, consistent with the formation of a pillared-layer compound, $\mathrm{CuNi}(\mathrm{CN})_{4}(\text { bipy })_{x}$, which is distinct from the previously reported material, $\mathrm{CuNi}(\mathrm{CN})_{4}\left[\right.$ bipy]. $\left(\mathrm{H}_{2} \mathrm{O}\right)_{2},{ }^{13}$ in which $-\mathrm{Cu}\left(\mathrm{OH}_{2}\right)_{2}-\mathrm{NC}-$ $\mathrm{Ni}(\mathrm{CN})_{2}-\mathrm{CN}-$ zig-zag chains are linked through 4,4'-bipyridine groups.
Further exploration of the $\mathrm{Cu}(\mathrm{CN})_{2}-\mathrm{Ni}(\mathrm{CN})_{2}$ phase diagram required a different method of synthesis in which $\mathrm{Cu}^{2+}$ and $\mathrm{Ni}^{2+}$ were simultaneously added to a cyanide solution. Using this method at more nickel-rich compositions than $\mathrm{CuNi}(\mathrm{CN})_{4}\left(\left(\mathrm{Cu}_{1 / 2} \mathrm{Ni}_{1 / 2}(\mathrm{CN})_{2}\right)\right.$, mixtures of $\mathrm{CuNi}(\mathrm{CN})_{4}$ and the hydrate $\mathrm{Cu}_{1 / 4} \mathrm{Ni}_{3 / 4}(\mathrm{CN})_{2} \cdot 3 \mathrm{H}_{2} \mathrm{O}$ were produced. At even higher nickel contents, a solid-solution region, $\mathrm{Cu}_{x} \mathrm{Ni}_{1-x}(\mathrm{CN})_{2} \cdot 3 \mathrm{H}_{2} \mathrm{O}(0 \leq x \leq 0.25)$, formed. The hydrates can be easily dehydrated to form the $\mathrm{Cu}_{x} \mathrm{Ni}_{1-x}(\mathrm{CN})_{2}$ phases shown in Figure 8 , which all adopt a nickel-cyanide-type structure. No mixed $\mathrm{Cu}$ (II)-

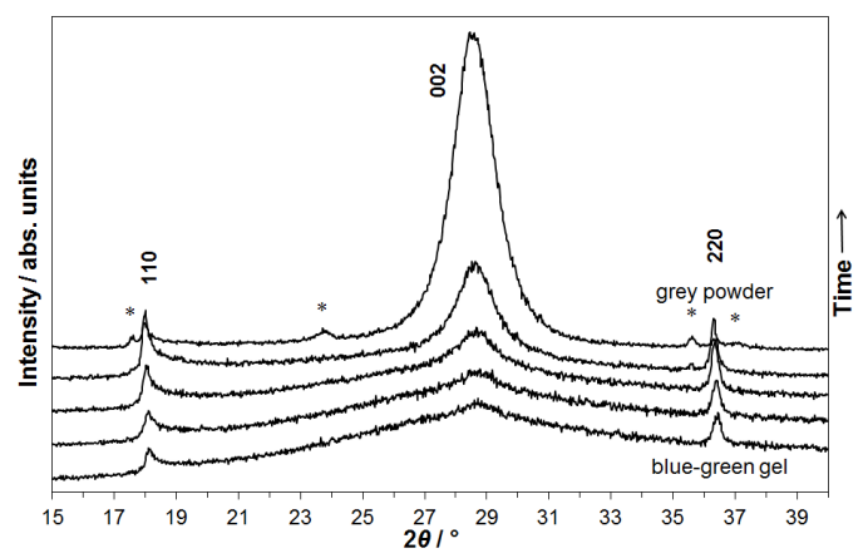

Fig. 7 In situ powder XRD patterns collected during the drying of $\mathrm{CuNi}(\mathrm{CN})_{4}$ as the sample turned from a blue-green gelatinous solid to a grey powder. The (002) reflection at $\sim 29^{\circ}$ increases in intensity on drying, whilst the (110) and (220) reflections remain substantially unchanged as the number of already-formed 2-D layers stacking together increases.

$\mathrm{Ni}$ (II) cyanides containing more copper than nickel could be prepared and the additional copper $\mathrm{Cu}(\mathrm{II})$ is reduced to $\mathrm{Cu}(\mathrm{I})$ in the form of the low-temperature polymorph of copper (I) cyanide, LT$\mathrm{CuCN} .{ }^{14}$ This reduction was also found when preparing the mixed $\mathrm{Cu}(\mathrm{I})-\mathrm{Cu}(\mathrm{II})$ phase, $\mathrm{Cu}_{2} \mathrm{Ni}(\mathrm{CN}) 5 \cdot 3 \mathrm{H}_{2} \mathrm{O}$, from $\mathrm{Cu}(\mathrm{II})$ and $\mathrm{Ni}(\mathrm{CN})_{4}{ }^{2-}{ }^{15}$ In copper rich compounds, $\mathrm{Cu}_{x} \mathrm{Ni}_{1-x}(\mathrm{CN})_{2} \quad(x>0.5)$, some $\mathrm{Cu}(\mathrm{II})$ atoms would have to be coordinated to the carbon end of cyanide groups and it might be this fact that leads to their instability. Although rare, it should be noted that $\mathrm{Cu}$ (II) can be attached to cyanide groups via the carbon end of the ligand, for example, in $\left[\mathrm{Cu}(\text { phen })_{2} \mathrm{CN}\right]^{+},{ }^{16}$ and of particular note is the molecular compound, $\mathrm{Cu}($ phen $)(\mathrm{CN})_{2}$, which has $\mathrm{Cu}$ (II) connected to two $\mathrm{CN}$ groups in this way. ${ }^{17}$

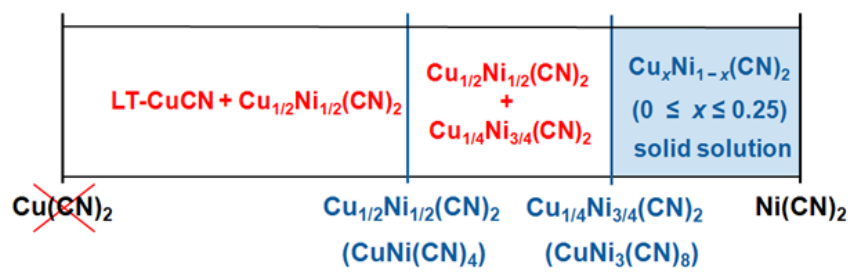

Fig. 8 Phases formed in the $\mathrm{Cu}(\mathrm{II})-\mathrm{Ni}(\mathrm{II})$-cyanide system.

In conclusion, we have prepared a number of new layered compounds, $\mathrm{Cu}_{x} \mathrm{Ni}_{1-x}(\mathrm{CN})_{2}$, consisting of $\mathrm{M}(\mathrm{CN})_{2}$ sheets structurally related to those found in $\mathrm{Ni}(\mathrm{CN})_{2}$. Addition of the synthon, $\left[\mathrm{Ni}(\mathrm{CN})_{4}\right]^{2-}$, to $\mathrm{Cu}^{2+}$ in aqueous solution, leads to the precipitation of anhydrous $\mathrm{CuNi}(\mathrm{CN})_{4}$. A combination of powder X-ray and total neutron diffraction, together with vibrational spectroscopy, has established that in $\mathrm{CuNi}(\mathrm{CN})_{4}\left(\left(\mathrm{Cu}_{1 / 2} \mathrm{Ni}_{1 / 2}(\mathrm{CN})_{2}\right)\right.$, the cyanide ligands bind so that their carbon atoms are coordinated only to nickel 
and their nitrogen atoms only to copper to generate ordered sheets containing square-planar $\mathrm{Ni}(\mathrm{CN})_{4}$ and $\mathrm{Cu}(\mathrm{NC})_{4}$ units. The stabilising of $\mathrm{Cu}^{\mathrm{II}}$ in an environment with cyanide as the only ligand present has not previously been reported. $\mathrm{CuNi}(\mathrm{CN})_{4}$ shows two-dimensional negative thermal expansion. We are currently analysing the phonon density of states of $\mathrm{CuNi}(\mathrm{CN})_{4}$ to discover why it shows very different thermal expansion behaviour from $\mathrm{Ni}(\mathrm{CN})_{2}$ perpendicular to the metal-cyanide layers.

In contrast to $\mathrm{CuNi}(\mathrm{CN})_{4}$, which can be prepared directly as an anhydrous compound from aqueous solution, other, more nickel-rich $\mathrm{Cu}_{\mathrm{x}} \mathrm{Ni}_{1-\mathrm{x}}(\mathrm{CN})_{2}$ compounds are formed via the hydrates, $\mathrm{Cu}_{\mathrm{x}} \mathrm{Ni}_{1-}$ ${ }_{x}(\mathrm{CN})_{2} .3 \mathrm{H}_{2} \mathrm{O}$, which can be easily dehydrated. A solubility gap exists between $\mathrm{CuNi}(\mathrm{CN})_{4}$, the most copper-rich phase that can be formed and a region of solid solution which exists between $\mathrm{Cu}_{1 / 4} \mathrm{Ni}_{3 / 4}(\mathrm{CN})_{2}$ and $\mathrm{Ni}(\mathrm{CN})_{2}$.

The authors thank the EPSRC (EP/G067279/1) and STFC (CMPC06101) for studentships for EM and EJB, respectively. The University of Reading is acknowledged for provision of the Chemical Analysis Facility (CAF).

\section{Notes and references}

a Department of Chemistry, University of Reading, Whiteknights, Reading RG6 6AD, UK. E mail: a.m.chippindale@rdg.ac.uk; Fax: +44 (0)1183786331; Tel: +44 (0)1183788448

${ }^{\mathrm{b}}$ present address: Jesus College, Oxford OX1 3DW, UK.

${ }^{c}$ ISIS Facility, Rutherford Appleton Laboratory, Chilton, Didcot, OX11 OQX, UK

${ }^{d}$ Institut Laue-Langevin, BP 156, F-38042 Grenoble Cedex 9, France

"FOOTNOTE: Although ordering of cyanide groups often occurs in mixedmetal cyanides, this is not always the case. For example, in the series of mixed-metal cyanides containing $\mathrm{Cu}(\mathrm{I}),\left(\mathrm{Cu}_{1 / 2} \mathrm{Au}_{1 / 2}\right) \mathrm{CN}$ contains ordered chains of the type $[\mathrm{Au}-\mathrm{C} \equiv \mathrm{N}-\mathrm{Cu}-\mathrm{N} \equiv \mathrm{C}-]_{n}$, whereas in $\left(\mathrm{Cu}_{1 / 2} \mathrm{Ag}_{1 / 2}\right) \mathrm{CN}$, there is head-to-tail cyanide disorder. ${ }^{6}$

${ }^{\dagger}$ FOOTNOTE: Although stacking together layers of $D_{4 h}$ symmetry in an $A B A B$ sequence is incompatible with true tetragonal symmetry, it is possible to construct orthorhombic models with a tetragonal metric. Furthermore, stacking disorder will lead to the long-range average metric appearing tetragonal, so that a model describing the local and intermediate structure in $\mathrm{Cmcm}$ is not in conflict with the indexing of the powder X-ray pattern as tetragonal.

$\dagger$ Electronic Supplementary Information (ESI) available: Synthesis of $\mathrm{CuNi}(\mathrm{CN})_{4}$ and $\mathrm{Cu}_{x} \mathrm{Ni}_{1-x}(\mathrm{CN})_{2}$ phases; X-ray powder diffraction patterns (variable temperature); neutron powder total diffraction details; thermal analysis; IR and Raman spectroscopy data, magnetic data. See DOI: $10.1039 / \mathrm{c} 000000 \mathrm{x} /$

1 A. G. Sharpe in 'The Chemistry of Cyano Complexes of the Transition Metals', Academic Press Inc London, 1976.

2 C. E. Housecroft and A. G. Sharpe, Inorganic Chemistry, Pearson Education Ltd, UK, $4^{\text {th }}$ Edn, $\mathrm{p} 768$.

3 S. J. Hibble, A. M. Chippindale, A. H. Pohl and A. C. Hannon, Angew. Chem. Int. Ed., 2007, 46, 7116.

4 A. L. Goodwin, M. T. Dove, A. M. Chippindale, S. J. Hibble, A. H. Pohl and A. C. Hannon, Phys. Rev B: Condens. Matter., 2009, B80, 054101 .
5 R. Mittal, M. Zbiri, H. Schober, E. Marelli, S. J. Hibble, A. M. Chippindale and S. L. Chaplot, Phys. Rev B: Condens. Matter., 2011, B83, 024301 .

6 A. M. Chippindale, S. J. Hibble, E. J. Bilbé, E. Marelli, A. C. Hannon, C. Allain, R. Pansu, and F. Hartl, J. Am .Chem..Soc., 2012, 134, 16387.

7 C. J. Brown, J. Chem. Soc. A, 1968, 2488.

8 M. Melnik, M. Kabesova, M. Dunaj-Jurco and C. E. Holloway, J. Coord. Chem., 1997, 41, 35.

9 Q. H. Wang, K. Kalantar-Zadeh, A. Kis, J. N. Coleman and M. S. Strano, Nature Nanotechnol, 2012, 7, 699.

10 Y. Mo and E. Kaxiras, Small, 2007, 3, 1253.

11 D. Yoon, Y. W. Son and H. Cheong Nano Lett., 2011, 11, 3227.

12 S. K. Mishra, R. Mittal, M. Zbiri, R. Rao, P. Goel, S. J. Hibble, A. M. Chippindale, T. Hansen, H. Schober and S. L. Chaplot, arXiv:1409.2305 [cond-mat.mtrl-sci].

13 O. Sereda and H. Stoeckli-Evans, Acta Cryst., 2008, C64, m221.

14 S. J. Hibble, S. G. Eversfield, A. R. Cowley and A. M. Chippindale, Angew. Chem. Int. Ed. 2004, 43, 628.

15 Y. L. Qin, R. X. Yao, G. X. Wu, M. M. Liu, and X. M. Zhang, Chem. Asian J., 2013, 8, 1587.

16 M. Dunaj-Jurco, I. Potocnak, J. Cibik and M. Kabesova, V. Kettmann And D Miklos, Acta Cryst. 1993, C49, 1479.

17 M. Wicholas and T. Wolford, Inorg. Chem., 1974. 13, 316.

\section{Graphical Abstract}

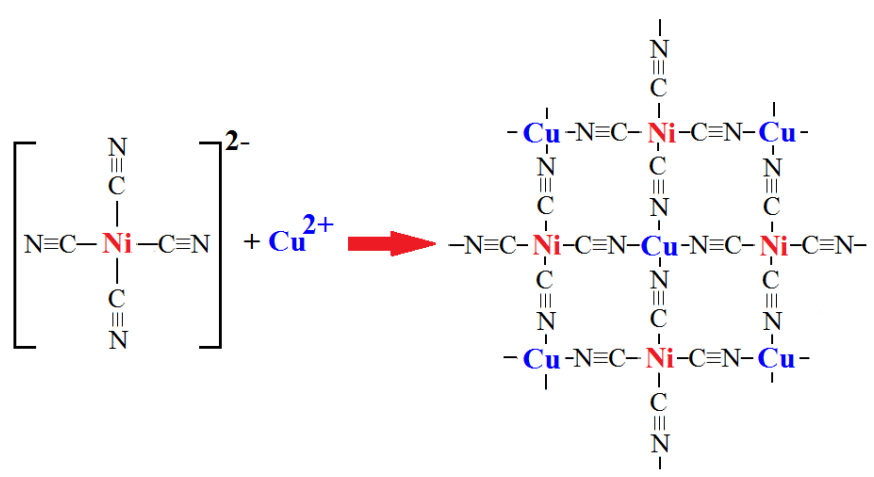

$\mathrm{Cu}(\mathrm{II})$ has been stabilised with square-planar coordination in a cyanide-only environment in the layered semiconducting material, copper-nickel cyanide, $\mathrm{CuNi}(\mathrm{CN})_{4}$, which shows 2-D negative thermal expansion. 